\title{
Packaging Innovation of Local Product Fermentation of Kania Dairy Farmers Group in Tajur Halang Village, Cijeruk, Bogor
}

\author{
Dina Dyah Saputri ${ }^{\text {a }}$, Meilisha Putri Pertiwi ${ }^{\text {a }}$, Rita Istiana ${ }^{a}$, \\ Annisa Wulan Agus Utami ${ }^{a}$, Susi Sutjihati ${ }^{a}$ \\ ${ }^{a}$ Lecturer of Biology Education Departement, Faculty of Teacher Training and Educational Science, Pakuan University \\ Jl. Pakuan, Tegallega, Central Bogor, Bogor City, West Java 16143 Indonesia
}

Corresponding author e-mail address: meilisha.putri@unpak.ac.id

\begin{abstract}
Community service program (PKM) for packaging innovation of local product fermentation of Kania Diary Farmers Group in Tajur Halang Village, Cijeruk Subdistrict, Bogor Regency has been conducted. It was held from April to Juli 2019. It aimed to empower Kania Diary Farmers Group in innovating milk fermentation product, introducing nutrition fact of es mambo kefir, and introducing well-packaged product. Its method were literature studied for an interesting packaging, field obeservation, kefir mambo ice production, nutrition analysed using proximat analysis, explanation about nutrition facts, implementation well-packaging, and discussion between instructors and Kania Group. After analysing the kefir mambo ice, it yielded 35 cal for $50 \mathrm{~g} / \mathrm{serving}$. It also contained $1 \mathrm{~g}$ protein, $1.5 \mathrm{~g}$ fat, and $1 \mathrm{~g}$ carbohydrate for $35 \mathrm{~g} / \mathrm{serving}$. All the nutrition containing in kefir mambo ice is good for a healthy body. Kania group members looked so enthusiasm and excited during the training. Hopefully, through this training, Kania group will develop better pacakaging for every single of its product.
\end{abstract}

Keywords: kefir, fermentation, milk, kania

\section{Introduction}

Livestock product development is a part of economy development strategic. It can fulfil increasing food necessity that relates to increasing people number. Besides that, it can make a high community income and create job vacancy. Moreover, it will be a blessing one if some areas have a great natural resource potency for livestock and farming.

Potential livestock agribusiness to develop is ruminant animal like goat and cattle. Ruminant animal has a high market product. Many people love this product. Culture and custom also support its 
high demand (Agus et al., 2018; Sodiq et al., 2019). So, protein nutrient are mostly taken from this product too.

West Java Feterinary Agency (2009), stated that Bogor Regency is the fifth largest milk production area. The others are Bandung, Garut, Kuningan, and Sumedang. Bogor Regency has a good potency for dairy cattle livestock. It is supported by fast growing dairy cattle population every year. Average of its population is $2,94 \%$ per year (Sinambela, 2013). It can be an opportunity for creating job and getting more income. In addition, community can simply consume it and of course absorbing its nutrition.

One of developed dairy cattle livestock areas in Bogor Regency is Tajur Halang Village, Cijeruk. This area already has dairy farmers groups named KANIA. This area has conducive weather and geographic. There are plenty of grass and water. The fresh air is also a proper factor for dairy cattle livestock (Sinambela, 2013). A supported area and a loyal farmers group are some factors to be a success community empowerment (Makihara et al., 2006).

Livestock has various commodities like chicken, duck, goat, sheep, pig, and cattle. Each of commodity contains protein, fat, calory, and vitamin. Nutrition from one commodity is different in number, size, function from another one. People's knowledge about nutrition makes them consume high nutrition food. Milk is an example. In advantage, milk has a complete nutition.

Milk has almost perfect nutrition. It is very sensitive towards physical and microbe influence. It also susceptible against milk damage. It inflicts lowness of milk storage. Now, food technology development has an alternative for milk processing. It can diverse milk product and lengthen milk storage time. One of the technologies is milk fermentation. Milk fermentation has a numerous benefit and savor for body (Panesar \& Parmjit, 2011; Sembada et al., 2016). Contained lactose in milk will be broken into more simple compound by fermentation, so for those-lactose intoleranced- can still enjoy the milk (Wilt et al., 2010; Swarastuti dan Safitri, 2011; Deng et al., 2015).

Kefir is one of popular milk fermentations nowadays. Kefir contains 0,5-1\% alcohol and 0,91,11\% (Rahman et al., 1992, Rosa et al., 2017). Kefir's milk is made from cattle milk, goat milk, or sheep milk that added kefir granule or seed as the starter (Kosikowski and Mistry, 1982; Ladokun et al., 2014). Indonesian tends to like kefir because of its benefit. It is believed empirically to prevent and cure various diseases like heart, kidney, lung, liver. It can also decrease cholesterol, increase appetation, and make body more powerfull and fresh. Kefir is also used to cure acnes by making kefir mask (Firdausi et al., 2010; John et al., 2015).

Kefir fermentation yields water for milk processing, meanwhile the rest is packaged into facial mask (Gao et al., 2016; Kim et al., 2018). Madigan et al. (2000) researched that kefir product can prevent Propionobacterium acnes, bacteria causing acnes. It is proved that kefir mask has potency become comestic product besides milk product. Both of them have economic value for community.

Local people in Tajur Halang village are mostly still selling milk without processing it. They have only a little home industry product. Unfortunately, their product has no a well packaging. Just like Magnier et al. (2016), many people judge the product by its cover. Better packaging, more better perception of product quality. They also don't know exactly the nutrition fact of its product. So, through our community service program (PKM), could we empower the community for improving the product? 


\section{Materials and Methods}

\subsection{Materials}

Community Service Activity was done from April to July 2019. The location was in Tajur Halang Village, Cijeruk Subdistrict, Bogor Regency. The analysis for product nutrition was done in FMIPA Pakuan University laboratory.

\section{2. .Methods}

The methods were used as follows:

1. Literature study for making a well pacakaging

2. Observing how the community is processing the product

3. Nutrition analyzing of kefir mambo ice

4. Presenting and explaining about kefir mambo ice nutrition fact

5. Discussion between instructors and community

Kefir mambo ice nutrition was analyzed by proximat analysis. The steps were:

\subsubsection{Ash Content (AOAC, 2005)}

Cup containing ash was drained inside oven for 1 hour at $105^{\circ} \mathrm{C}$. After that, it was frozen for 15 minutes inside dessicator and was balanced to gain constant weigh. Five grams sample was put into ash cup and burnt on flame until zero smoke. Next, it was put into oven for 1 hour at $600^{\circ} \mathrm{C}$ and balanced to gain constant weigh. Ash content was determined with formula:

$$
\begin{aligned}
& \text { Ash content }(\%): \frac{\mathrm{b}-\mathrm{c}}{\mathrm{a}} \times 100 \% \\
& \begin{aligned}
\text { Description : } \mathrm{a} & =\text { sample initial/original weigh }(\mathrm{gr}) \\
\mathrm{b} & =\text { sample and cup final weigh }(\mathrm{gr}) \\
\mathrm{c} & =\text { empty cup weigh }(\mathrm{gr})
\end{aligned}
\end{aligned}
$$

\subsubsection{Water Content (AOAC, 2005)}

First step to analyze water content was drained up the cup inside oven for 1 hour at $105^{\circ} \mathrm{C}$. Cup was put inside dessicator ( \pm 15 minutes) and let it be cold, finally balanced it. The cup was balanced again until constat weigh. Five grams example was inserted into that cup, then drained it up inside the oven for 5 hours at $105^{\circ} \mathrm{C}$ or until constant weigh. Lastly, the cup was inserted into dessicator and let it be cold then balanced it again. Water content formula was:

$$
\begin{aligned}
& \text { Water content }(\%): \frac{a-b}{a} \times 100 \% \\
& \text { Description : } \mathrm{a}=\text { sample initial/original weigh }(\mathrm{gr}) \\
& \mathrm{b}=\text { drained sample weigh }(\mathrm{gr})
\end{aligned}
$$

\subsubsection{Fat Content (Santi et al., 2012)}

Two grams-free water sample was extracted with n-hexane organic solvent inside soxlet for 6 hours. Extraction sample was evaporeated by dry-shaking and put inside oven at $105^{\circ} \mathrm{C}$. Lastly, sample was chilled inside dessicator and balanced until konstan weigh. The formula was:

$$
\text { Fat content }(\%)=\frac{\text { Fat weigh }}{\text { Sample weigh }} \times 100 \%
$$




\subsubsection{Protein Content (Santi et al., 2012)}

0,1 gr of sample was inserted into erlenmeyer flask then it was added 2,5 $\mathrm{ml}$ of solid sulphuric acid $\left(\mathrm{H}_{2} \mathrm{SO}_{4}\right), 1 \mathrm{gr}$ of catalyst, and some boiling stones. Solution was destructed to gain clear solution and then chilled it. After that, it was moved into destilation tool and was added $15 \mathrm{ml}$ of $50 \% \mathrm{NaOH}$. Erlenmeyer flask was containing $25 \mathrm{ml}$ of $\mathrm{HCl} 0,02 \mathrm{~N}$ and $2-4$ mengsel indicator drops (mix of $0,02 \%$ red methyl in alcohol and $0,02 \%$ blue methyl in alcohol (2:1) under condenser). Condenser tube tip must be submerged inside $\mathrm{HCl}$. Destilation was done until 2 times higher of solution volume inside erlenmeyer compare with the beginning. Condenser tip was rinsed with aquadest (inside erlenmeyer). The solution inside erlenmeyer was titrated with $\mathrm{NaOH} 0,02 \mathrm{~N}$ until color changing from green to purple. Lastly, we could get from this formula:

$$
\begin{aligned}
& \text { Crude protein content }(\%)=\frac{(\mathrm{a}-\mathrm{b}) \times \mathrm{N} \times 0,014 \times 6,25 \times 100 \%}{\mathrm{~W}} \\
& \begin{aligned}
\text { Description }: \mathrm{a} & =\mathrm{ml} \mathrm{NaOH} \text { for blanc titration } \\
\mathrm{b} & =\mathrm{ml} \mathrm{NaOH} \text { for sample titration } \\
\mathrm{N} & =\mathrm{NaOH} \text { normality } \\
\mathrm{W} & =\text { sample weigh }(\mathrm{gr})
\end{aligned}
\end{aligned}
$$

\subsubsection{Carbohydrate Content by difference (Santi et al., 2012)}

Carbohydrate content could be count by this formula :

$$
\begin{aligned}
& \text { Carbohydrate content }(\%)=100 \%-(\mathrm{A}+\mathrm{B}+\mathrm{C}+\mathrm{D}) \\
& \text { Description : }
\end{aligned}
$$

\begin{tabular}{l|l|l} 
A $=$ & NUTRITION FACTS & Water content \\
$\mathrm{B}=$ Ash & Serving size: 50 gram & content \\
$\mathrm{C}=$ Fat & Serving size per pack serving & content \\
$\mathrm{D}=$ & & Protein content
\end{tabular}

\section{Results and Discussion}

Kefir milk is made of

cattle milk, goat milk, and sheep milk with a powdery substance or kefir starter (Kosikowski dan Mistry, 1982). We named our product as kefir mambo ice. It contains 35 energy calory for serving size: $50 \mathrm{~g}$ in one pack serving. It has $1 \mathrm{~g}$ protein, $1.5 \mathrm{~g}$ fat, and $1 \mathrm{~g}$ carbohydrate per $35 \mathrm{~g}$ serving size. It's good for our body. In Indonesia, community starts loving kefir. Community believes kefir empirically could prevent and cure various diseases like heart, kidney, lung, liver. It could also decrease cholesterol, increase appetation, and make body more powerfull and fresh. Moreover, its function as kefir mask for curing acnes problems (Firdausi et al., 2010).

Table 1: Kefir mambo ice nutrition facts 


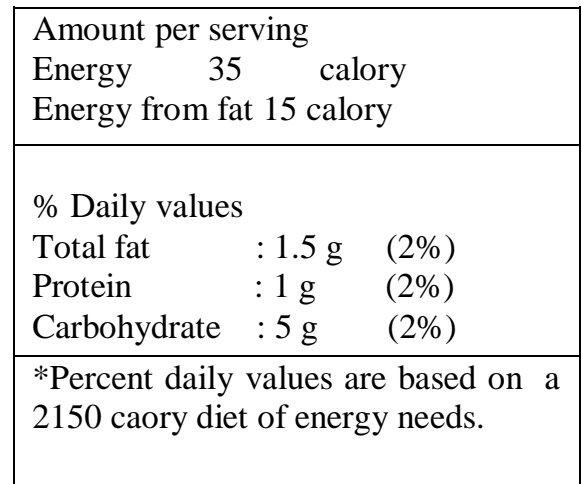

\begin{tabular}{llll}
\hline Parameter & Unit & Result & Method \\
\hline Water & $\%$ & 85.1 & SNI 01-2891-1992, butir 5.1 \\
Ash & $\%$ & 0.61 & SNI 01-2891-1992, butir 6.1 \\
Protein & $\%$ & 1.92 & SNI 01-2891-1992, butir 7.1 \\
Fat & $\%$ & 2.84 & SNI 01- 2891-1992, br \\
Carbohydrate & $\%$ & 9.53 & IK 7.2.3 \\
\hline
\end{tabular}

Milk has almost a perfect nutrition. People from all age range loves it. On the other hand, milk is very sensitive towards physical and microbe influence. It also susceptible against milk damage. So, it inflicts lowness of milk storage.

Recently, food technology development has an alternative for milk processing. It can diverse milk product and lengthen milk storage time. One of the technologies is milk fermentation. Milk fermentation has a numerous benefit and savor for body. Contained lactose in milk will be broken into more simple compound by fermentation, so for those -lactose intoleranced- can still enjoy the milk (Swarastuti dan Safitri, 2011).

Besides explaining the nutrition of kefir mambo ice, we also implemented a well packaging. We made colourful kefir mambo ice and fancy yet informative label. A good packaging can increase sales of products, reduces the level of inventory, which yields to higher profitability (Azad et al., 2012; Mohebbi \& Behzad; 2014) Of course, the label containing product name, nutrition facts, our identity, tagline, and the benefit. A good label with detailed and precise information on product could significantly impact customer's confidence in buying the products (Wells et al., 2007; \& Rund, 2009). It can be seen in Figure 1. After the training, we hope the community use this packaging innovation, completed with the nutrition facts, etc. Besides that, they will not always sell the raw milk only, but process the milk into various products. Finally, a good packaging can increase sales of products which yields to higher profitability (Tosida et al., 2016; 2019).

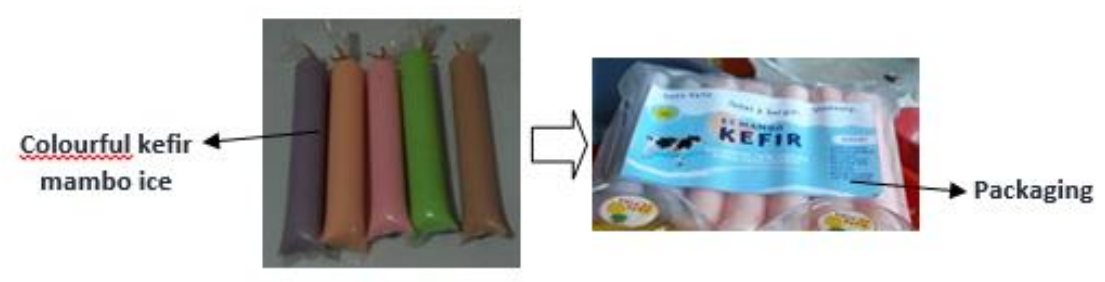


Figure 1: Kefir mambo ice packaging and label

\section{Conclussion}

Kefir mambo ice is the end product of community service program. The product is covered with a good packaging products and label with detailed and precise information. The product also contains a good nutrition like 35 calory per $50 \mathrm{~g}$ serving size and enough protein, fat, and carbohydrate.

\section{Acknowledgments}

We would like to say a big thank you for LPPM, Pakuan University for funding this PKM. The last but not least, for Kania Group in Tajur Halang Village, Cijeruk, Bogor for a very warm and well cooperated.

\section{References}

Agus, Ali \& Widi, Tri Satya. (2018). Current situation and prospect of beef cattle production in Indonesia: a brief review. Asian Australasian Journal of Animal Sciences. 41.

Azad, Naser \& Hamdavipour, Leila. (2012). A study on effects of packaging characteristics on consumer's purchasing confidence. Management Science Letters. 2. 397-402. 
Badan Pusat Statistik Kecamatan Cijeruk, Kabupaten Bogor. (2016). CV. Prima : BPS Kabupaten Bogor Kabupaten Bogor. (2016). CV. Prima : BPS Kabupaten Bogor.

Deng, Yanyong Misselwitz, Benjamin, Dai, Ning \& Fox, Mark. (2015). Lactose Intolerance in Adults: Biological Mechanism and Dietary Management. Nutrients. 7. 8020-8035.

Firdausi, D., Saifudin, A.Y., \& Haryono, D.P. (2010). Kristal Algae Sebagai Obat Alternatif Penyembuhan Kanker Kolorektal. http://www.lipi.go .id/kompetisi/kompetisi.cgi?ringkasan\& 1271731966\&1278996981\&2 010. 21 Mei 2013.

Gao, J., Yu, D., Chen, Dengzhou, He, G., Gong, Z., Wang, Qian, Huo, \& Junsheng. (2016). The research progress of traditional fermented milk kefir. 16. 204-211.

Hutkins, R.W. (2006). Microbiology and Technology of Fermented Foods. Iowa: Blackwell.

Iskandar, Zaki, M., Mulyati, S., Fathanah, U., Sari, I., \& Juchairawati, 2010. Pembuatan Film Selulosa dari Nata de Pina. Jurnal Rekayasa Kimia dan Lingkungan, Vol. 7, No. 3, hal. 105- 111.

John, S. \& Deeseenthum. (2015). Properties and benefits of kefir - A review. Songklanakarin Journal of Science and Technology. 37. 275-2

Kim, Dong-Hyeon, Jeong, Dana, Kim, Hyunsook \& Seo, Kun-Ho. (2018). Modern perspectives on the health benefits of kefir in next generation sequencing era: Improvement of the host gut microbiota. Critical Reviews in Food Science and Nutrition. 59. 00-00.

Kosikowski, F. \& Mistry, V. V. 1982.Cheese and Fermented Milk Foods 3rd Edition.F. V. Kosikowski and Associates. New York.

Ladokun, Olusola \& Oni, Sarah. (2014). Fermented Milk Products from Different Milk Types. Food and Nutrition Sciences. 05. 1228-1233.

Madigan, M. T., Martinko, J. M., \& Parker, J. (2000). Brock Biology of Microorganisms, 9th Edition. Prentice-Hall Inc. New Jersey.

Magnier, Lise \& Schoormans, Jan \& Mugge, Ruth. (2016). Judging a product by its cover: Packaging sustainability and perceptions of quality in food products. Food Quality and Preference. 53. 132142.

Makihara, Daigo, Mtasiwa, Benedict, Kembo, Jane, Bazirake, Bernard, Morimoto, Yasuyuki, Maundu, Patrick, Kariuki, Patrick, \& Wakhu, Patrick. (2006). Concept and Process of "Community Empowerment and Networking Program. Innovation Africa Symposium. 52-53.

Mohebbi, \& Behzad. (2014). The art of packaging: An Investigation Into the Role of Color in Packaging, Marketing, and Branding. International Journal of Organizational Leaderhip. 3. 92-102. 
Panesar, \& Parmjit. (2011). Fermented Dairy Products: Starter Cultures and Potential Nutritional Benefits. Food and Nutrition Sciences. 2. 47-51.

[PusBangTepa] Pusat Penelitian dan Pengembangan Teknologi Pangan. (1981). Sayur Asin Paket Industri Pangan Untuk Daerah Pedesaan. Bogor:IPB

Rahman, A., Fardiaz, S., Rahaju, W. P., Suliantari, \& Nurwitri, C. C. (1992). Bahan Pengajaran Teknologi Fermentasi Susu.Pusat Antar Universitas Pangan dan Gizi.Institut Pertanian Bogor.

Rosa, D., Dias, M., Grześkowiak, Ł, Reis, S., Conceição, L., \& Peluzio, M. (2017). Milk kefir: Nutritional, microbiological and health benefits. Nutrition Research Reviews, 30(1), 82-96.

Rundh, Bo. (2009). Packaging design: Creating competitive advantage with product packaging. British Food Journal. 111. 988-1002.

Sembada, Pria, Guillaume, Duteurtre, Purwanto, Bagus, \& Suryahadi,. (2016). Improved milk production performance of smallholder farms in West Java (Indonesia). Tropical Animal Health and Production. 48.

Sinambela D. (2013). Analisis Kelayakan Usaha Sapi Perah Kelompok KANIA di Desa Tajur Halang, Kecamatan Cijeruk, Kabupaten Bogor. Bogor : Institut Pertanian Bogor.

Sodiq, A., Yuwono, Pambudi, Sumarmono, Juni, Wakhidati, Y., Rayhan, M., Sidhi, A. \& Maulianto, A. (2019). Improving production system of beef cattle agribusiness. IOP Conference Series: Earth and Environmental Science. 250. 012050.

Swarastuti A, \& Safitri MF. (2013). Kualitas Kefir Berdasarkan Konsentrasi Kefir Grain. Jurnal Aplikasi Teknologi Pangan, Vol.2 No.2.

Tosida E.T., Maryana, S., Thaheer, H., \& Damin, F.A. (2016). Visualization model of Small Medium Enterprises (SMEs) telematics services potentiality map in Indonesia. Published in:International Conference on Information \& Communication Technology and Systems (ICTS), 2015. Added toIEEExplorer. January $14^{\text {th }} 2016$. doi : $10.1109 /$ ICTS.2015.7379890.

Tosida, E.T., Ardiansyah, D., Walujo, A.D., Sofyandi, A. (2019). System Design of Augmented Reality Technology to Strengthen Sustainable Imaging of Kujang Products Based on Local Culture. International Journal of Recent Technology and Engineering (IJRTE), Vol. 8, Issue 4, Nov 2019, pp 5940- 5949.

Usmiati S, \& Sunarlim R. (2007). Pengaruh Suhu dan Lama Penyimpanan Terhadap Keasaman dan Kadar Alkohol.Semiloka Nasional Prospek Industri Sapi Perah Menuju Perdagangan Bebas 2020:528-533.

Wells, L.E., Farley, Heather, \& Armstrong, G.A.. (2007). The importance of packaging design for ownlabel food brands. International Journal of Retail \& Distribution Management. 35.

Wilt, Timothy, Shaukat, Aasma, Shamliyan, Tatyana, Taylor, Brent, Macdonald, Roderick, Tacklind, 
James, Rutks, Indulis, Schwarzenberg, Sarah, Kane, Robert, \& Levitt, Mi. (2010). Lactose intolerance and health. Evidence Report/Technology Assessment. 192. 1-410.

Zubaidah E, \& Halim CN. (2013). Stusi Kemampuan Probiotik Isolat Bakteri Asam Laktat Penghasil Eksopolisakarida Tinggi Asal Sawi Asin (Brassica juncea). Jurnal Pangan dan Agroindustri Vol.1 No.1 : 129-137. 